\title{
ANALYSIS OF RECIRCULATION ZONE AND IGNITION POSITION OF NON-PREMIXED BLUFF-BODY FOR BIOGAS MILD COMBUSTION
}

\author{
M.M. Noor ${ }^{1,2, *}$, Andrew P. Wandel ${ }^{1}$ and Talal Yusaf ${ }^{2,3}$ \\ ${ }^{1}$ Computational Engineering and Science Research Centre, Department of Mechanical \\ and Mechatronic Engineering, University of Southern Queensland (USQ), Australia \\ ${ }^{2}$ Faculty of Mechanical Engineering, Universiti Malaysia Pahang (UMP), Malaysia \\ ${ }^{3}$ National Centre for Engineering in Agriculture, USQ, Australia \\ *Corresponding author: Muhamad.MatNoor@usq.edu.au / muhamad@ump.edu.my
}

\begin{abstract}
Combustion ignition study is important due to the combustion process becoming more lean and efficient. This paper studied the recirculation zone and ignition location for the bluff-body non-premixed MILD burner with biogas used as fuel. The location of the ignition was critical to ensure that the spark energy supply during the ignition process can successfully ignite the mixture of air and fuel. The numerical calculations were done using the commercial code ANSYS-Fluent to simulate the furnace with a bluffbody burner to determine the recirculation zone. The turbulence model used was the realizable k- $\varepsilon$ model. The inner recirculation zone between the air and fuel nozzle is the best location for the ignition point, since the low velocity of air and fuel mixing will assist the ignition process. This is because the ignition energy will have time to ignite the mixture in the low speed turbulent swirl flow. The most suitable location with the highest possibility of ignition is the center of the recirculation zone.
\end{abstract}

Keywords: Computational fluid dynamics; bluff-body MILD burner; recirculation zone; biogas; spark ignition.

\section{INTRODUCTION}

Economic development and the increase of the population are leading to increased energy demand. Currently, the overall energy demand is highly dependent on the combustion of fossil fuel, which is projected to fulfill about $80 \%$ of these energy requirements (IEA, 2009; Maczulak, 2010). With the current consumption rate, the fossil fuel will be depleted by 2042 (Shafiee \& Topal, 2009). Improvement of the combustion process is crucial and will significantly impact the efficiency of energy generation (Aziz, Firmansyah, \& Shahzad, 2010). One technique to improve thermal efficiency and reduce $\mathrm{NO}_{\mathrm{x}}$ is Moderate or Intense Low-oxygen Dilution (MILD) combustion (Dally, Karpetis, \& Barlow, 2002: Dally, Riesmeier, \& Peters, 2004; Cavaliere \& de Joannon, 2004; Cavaliere, de Joannon, \& Ragucci, 2008; Wandel, Noor, \& Yusaf, 2012). This technique is also known as Flameless Oxidation (FLOX) by Wünning (1991, 1996), High-Temperature Air Combustion (HiTAC) by Katsuki and Hasegawa (1998) and Tsuji et al. (2003) and Colourless Distributed Combustion (CDC) by Arghode and Gupta $(2010,2011)$. The main characteristics of MILD combustion are an elevated temperature of reactants and low temperature increase in the combustion process. To increase the reactant temperature, the exhaust gas recirculation (EGR) concept and input air preheat is normally implemented. The hot exhaust gases are utilized to heat and dilute the oxygen in the injected fresh air. 
In normal combustion systems, greater attention is given to the fully burning state, like combustion efficiency, heat release rates, flame stability, pollutant emission or flame extinction. Combustion research has also focused on these aspects (Mastorakos, 2009; Mohanamurugan, \& Sendilvelan, 2011; Ghobadian, Najafi, \& Nayebi, 2013). Ignition process research receives less attention, especially spark ignition of non-premixed flames. In the experimental work by Birch, Brown, and Dodson (1981), the probability of successful ignition was correlated with the probability of finding a mixture within the flammability limits. Mastorakos (2009) studied the ignition of non-premixed flames and the effect of turbulence models on the fuel and oxidizer mixing process. This turbulent mixing process later affects the probability of ignition. The spark ignition has been studied experimentally and numerically by a few researchers (Birch et al., 1981; Ahmed et al., 2007; Marchione, Ahmed, \& Mastorakos, 2009; Mastorakos, 2009; Oldenhof et al., 2010, 2011) and still needs more attention. A tungsten electrode was used by Ahmed et al. $(2006,2007)$ as an ignition rod for the spark ignition because it can withstand up to $3200 \mathrm{~K}$. They studied electrode diameters of $1.0 \mathrm{~mm}, 0.7 \mathrm{~mm}$, and $0.5 \mathrm{~mm}$ for ignition probability and found that the ignition probability was increased with the decrease of the electrode diameter and increase in spark energy. Ahmed (2006) also concluded that the ignition probability is nearly always decreased with increasing flow velocity. This is in line with the result of later studies (Ahmed et al., 2007) that the ignition probability consistently decreased with increasing bulk velocity. The ignition location should be in the recirculation zone where the velocity is very low so that the energy supply by the spark ignition rod will be utilized to ignite the mixture and not flushed away by the high velocity of air or fuel or both reactants.

This paper examines the location and shape of the recirculation zone for a MILD combustion bluff-body burner. The purpose of the recirculation zone study in this paper is to determine the best location for the spark ignition rod installation for the experimental MILD burner. The experimental test rig for the MILD burner is developed to carry out the experimental study on MILD combustion for open furnace. The ignition used in the experimental study is a spark ignition type, which needs accurate location to ensure that the mixture will properly ignite to start the flame.

\section{BIOGAS AND ENERGY BALANCE}

Biogas is a low heating value gas also known as low calorific value (LCV) gas. Biogas consists of a mixture of $50-75 \%$ methane and $25-50 \%$ carbon dioxide. The lower the methane content, the lower the heating value for the biogas. Table 1 shows a comparison of the energy balance for biogas with $60 \%$ methane and $40 \%$ carbon dioxide and natural gas with $97 \%$ methane. The summary was made for a furnace that operates in flameless mode with biogas and natural gas, and the conventional mode with natural gas. The supply of thermal energy was constant at about $21 \mathrm{~kW}$ for all combustion modes. The energy calculated includes all the input to the combustion chambers, which are fuel, air through the cooling tubes and air that will be preheated by the regenerative honeycombs. The efficiency of combustion with the conventional mode is only $41.4 \%$, whereas for biogas and natural gas in MILD mode it is $68 \%$ and $70 \%$ respectively. Comparison of the efficiency of the flameless mode for biogas and natural gas shows that biogas is only $2 \%$ lower than natural gas. This is not a big issue compared to the benefit of biogas to global warming and the greenhouse gas effect. 
Table 1. Biogas and natural gas energy balance (Colorado et al., 2010).

\begin{tabular}{lccc}
\hline Combustion mode (fuel) & $\begin{array}{c}\text { Flameless } \\
\text { mode } \\
\text { (biogas) }\end{array}$ & $\begin{array}{c}\text { Flameless } \\
\text { mode } \\
\text { (natural gas) }\end{array}$ & $\begin{array}{c}\text { Conventional } \\
\text { mode } \\
\text { (natural gas) }\end{array}$ \\
\hline $\begin{array}{l}\text { Energy input (including fuel } \\
\quad \text { combustion air + } \\
\quad \text { cooling air) (kW) }\end{array}$ & 21.13 & 21.31 & 21.02 \\
$\begin{array}{c}\text { Energy losses through the } \\
\quad \text { wall (kW) }\end{array}$ & 3.00 & 3.07 & 3.20 \\
$\begin{array}{c}\text { Energy removed by the } \\
\text { cooling tubes (kW) }\end{array}$ & 14.39 & 14.99 & 8.71 \\
$\begin{array}{c}\text { Energy output through the } \\
\text { chimney (kW) }\end{array}$ & 2.72 & 1.39 & 8.25 \\
$\begin{array}{c}\text { Energy of the combustion } \\
\text { products after the } \\
\text { regenerative system }(\mathrm{kW})\end{array}$ & 1.01 & 1.36 & 0 \\
Efficiency $(\%)$ & 68.0 & 70.0 & 41.4 \\
\hline
\end{tabular}

In order to recover the energy losses through the exhaust gas, the EGR concept was applied to the combustion system. EGR behaves differently to heat regenerators and it works by recirculating a portion of the flue gas back to the combustion chamber through the EGR pipe. Lloyd and Weinberg (1974), Weinberg (1996) and Choi and Katsuki $(2001,2002)$ used the concept of heat recirculation combustion. Weinberg (1996) demonstrated it in his famous Swiss-roll burner by transferring the heat from burned products to the unburned fresh mixture. He used double walls that separated the products and the mixture and acted as a heat regenerator. EGR was also used as a solution to avoid $\mathrm{NO}_{\mathrm{x}}$ and soot formation. EGR with MILD combustion was used by Wünning and Wünning (1997), Katsuki and Hasegawa (1998), and many other researchers have utilised EGR in their experiments and numerical studies (Tsuji et al., 2003; Cavaliere et al., 2004, 2008; Colorado, Herrera, \& Amell, 2010; Noor, Wandel, \& Yusaf, 2012a, 2012b, 2012c and Abtahizadeh, Oijen, \& Goey, 2012). The EGR volume ratio is:

$$
\text { EGR Ratio }=\frac{\text { recycled exhaust gas volume }}{\text { total exhaust gas volume }}
$$

EGR will dilute the oxygen and increase the intake air temperature to the combustion chamber. The volume of hot exhaust gas to flow back into the combustion chamber depends on the level of oxygen dilution and air pre-heating needed. EGR will reduce $\mathrm{NO}_{\mathrm{x}}$ emissions of the oxygenated fuels by more than $55 \%$ since it reduces both the pressure (Raj \& Sendilvelan, 2010) and the maximum combustion temperature.

\section{CFD MODELING}

Prior to this century, experimental work has been an effective method for testing and optimization due to the limited capacity to do huge data calculation. Modern technology means computational modeling of complex problems is now feasible and preferable to 
expensive, comprehensive experimental studies (Chandrasekharan, 2013). Building computational models gives researchers deeper insights into problems than building an experimental setup. Despite the benefits of computational methods, however, the experiment method is still an important step to compare and validate the computational result. This feedback can be used to improve the computational method. Computational Fluid Dynamics (CFD) offers a cost-effective method especially at the beginning of the combustor design and parameter setting stage. It was therefore used here to study the recirculation zone and optimize the ignition location. The first CFD modeling work for MILD combustion was started by the Japanese heating industry where a few researchers (Ishii, Zhang, \& Sugiyama, 1997; Zhang, Ishii, \& Sugiyama, 1997; Hino, Zhang, \& Ishii, 1998) carried out simulations of a continuous slab reheating furnace with emphasis on $\mathrm{NO}_{\mathrm{x}}$ formation. The simulation work was successful and continued with an experimental technique. In the current work, the biogas configuration of $60 \%$ methane and $40 \%$ carbon dioxide (molar base) was used. This ratio of biogas was also used by a few other researchers (Pomeroy, 2008; Colorado et al., 2010; Scholz \& Ellner, 2011; Salunkhe, Rai, \& Borker, 2012; Noor et al., 2012a, 2012b, 2012c; Keramiotis \& Founti, 2013). Table 2 shows the CFD setup and typical data for the combustion chamber.

Table 2. Typical data for furnace and combustion chamber.

\begin{tabular}{|c|c|}
\hline Item & Data \\
\hline Fuel & $60 \%$ methane mixed with $40 \%$ carbon dioxide \\
\hline Oxidizer & Atmospheric air and syntactic air at room temperature \\
\hline Fuel inlet & $1 \times 78.5 \mathrm{~mm}^{2}$ \\
\hline Air inlet & $4 \times 78.5 \mathrm{~mm}^{2}$ \\
\hline Chamber size & Diameter $600 \mathrm{~mm}$, height $860 \mathrm{~mm}$ \\
\hline EGR & 4 EGR with $1962.5 \mathrm{~mm}^{2}$ each inlet \\
\hline Mesh method & $\begin{array}{l}\text { Tetrahedrons (patch conforming method) with 111,975 } \\
\text { nodes and 501,831elements }\end{array}$ \\
\hline Radiation model & $\begin{array}{l}\text { Discrete ordinate (DO) model. Absorption coefficient: } \\
\text { Weighted sum of gray gas (WSGGM) model. }\end{array}$ \\
\hline
\end{tabular}

The combustion chamber consists of four EGR pipes each with an inner diameter of $1962.5 \mathrm{~mm}^{2}$. The MILD combustion simulation involved the solution of the chemical reactions, turbulent flows, heat transfer and species transport. In this work, the Reynolds-Averaged Navier-Stokes (RANS) equations together with a realizable k- $\varepsilon$ turbulence model (Shih et al., 1995) [developed based on the standard k- $\varepsilon$ turbulence model (Launder \& Spalding, 1974)] are solved using commercial CFD software ANSYS Fluent 14.0 (Fluent, 2011). The discrete ordinate (DO) radiation model (Chui \& Raithby, 1993) and absorption coefficient of weighted sum of gray gas (WSGGM) model is used in this work. Figure 1 shows the early stage of the combustion process about 15 seconds after the ignition started. Figure 2 indicates that when MILD is achieved, the temperature inside the combustion chambers will be homogeneous.

\section{RECIRCULATION ZONE}

Figure 3 shows the flame re-circulation zone on the schematic bluff-body burner diagram for a $3.0 \mathrm{~mm}$ fuel nozzle and $10.0 \mathrm{~mm}$ annulus air nozzle as co-flow; this nozzle angle is $22^{\circ}$. The fuel velocity at exit is $75 \mathrm{~m} / \mathrm{s}$ and air is at $5 \mathrm{~m} / \mathrm{s}$. The recirculation zone was formed and the center of the recirculation zone was detected at 
$\mathrm{x} / \mathrm{D}=0.25$ and $\mathrm{r} / \mathrm{D}=0.25$. Figure 5(a) shows that there are other two zones in the flame schematic diagram, the flame neck zone and flame jet zone.

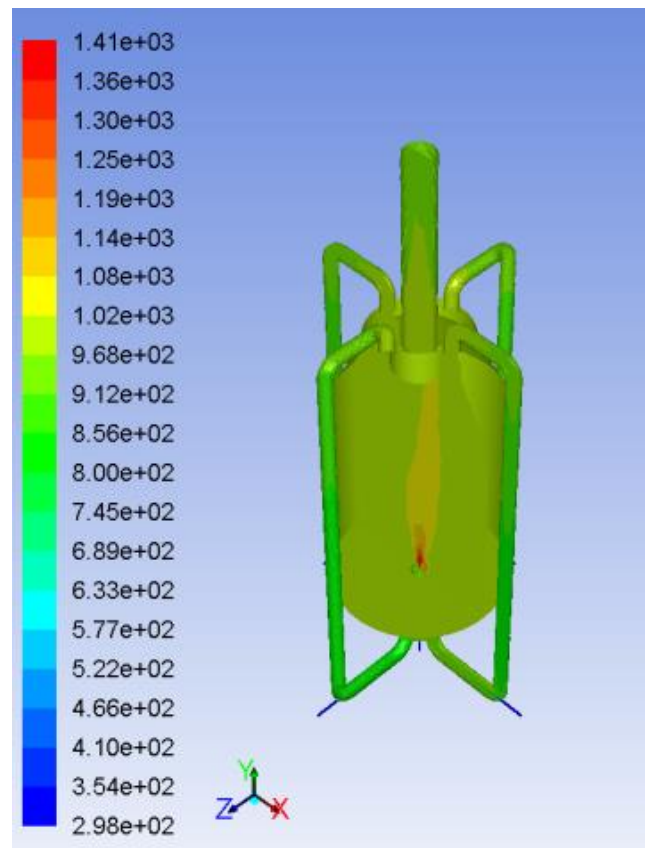

(a)

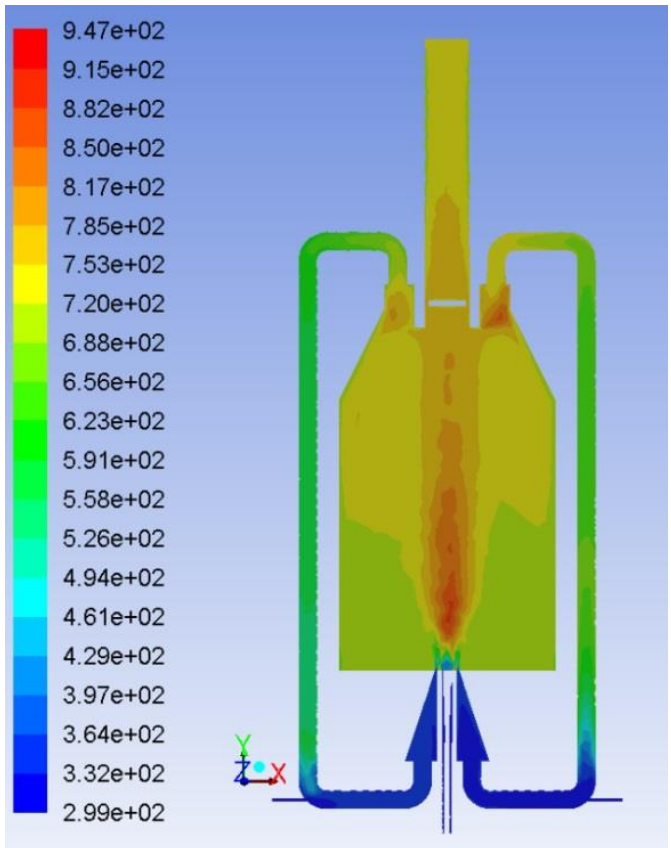

(b)

Figure 1. Early stage of the combustion process in open furnace, prior to MILD combustion state: (a) 3D image; (b) 2D image.

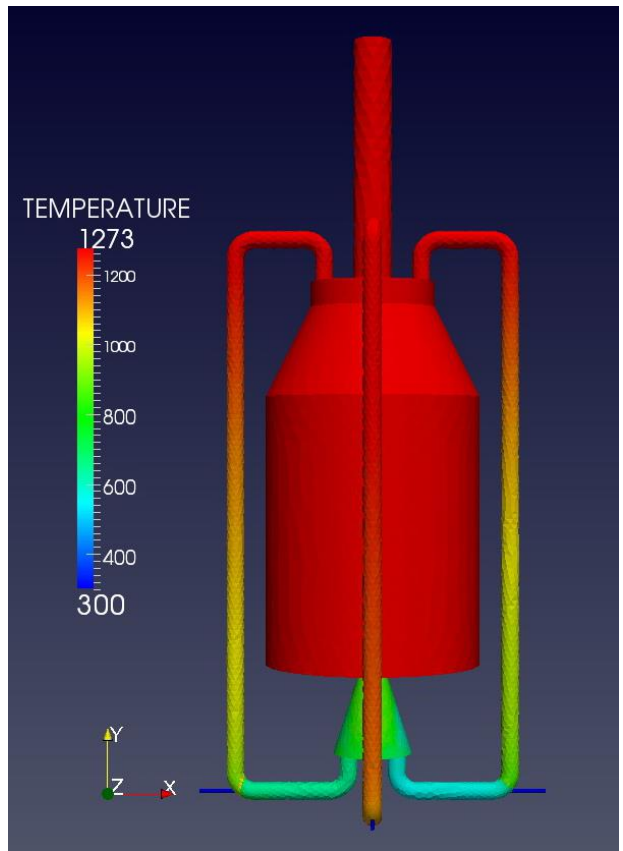

(a)

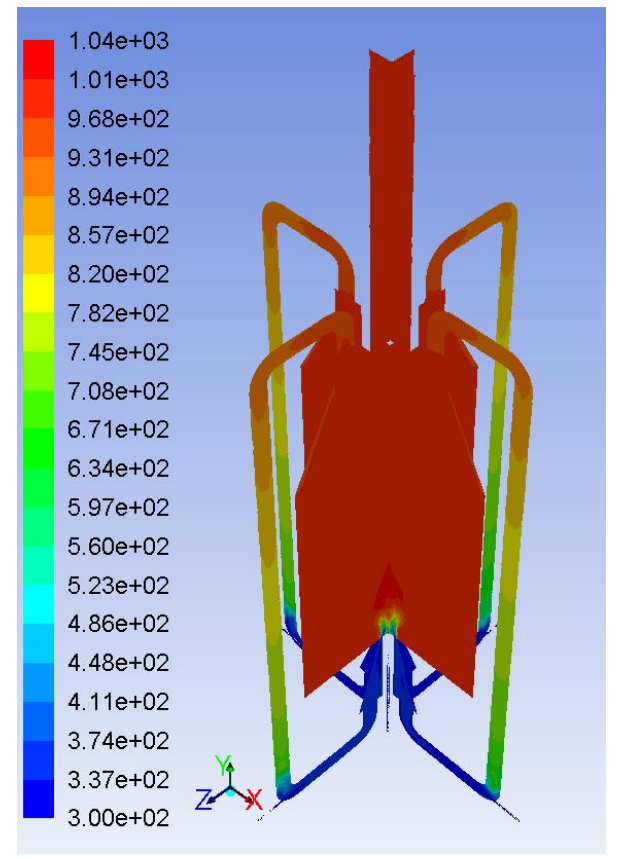

(b)

Figure 2. MILD combustion state achieved: (a) furnace wall temperature at $1273 \mathrm{~K}$; (b) inside chamber temperature $1040 \mathrm{~K}$. 


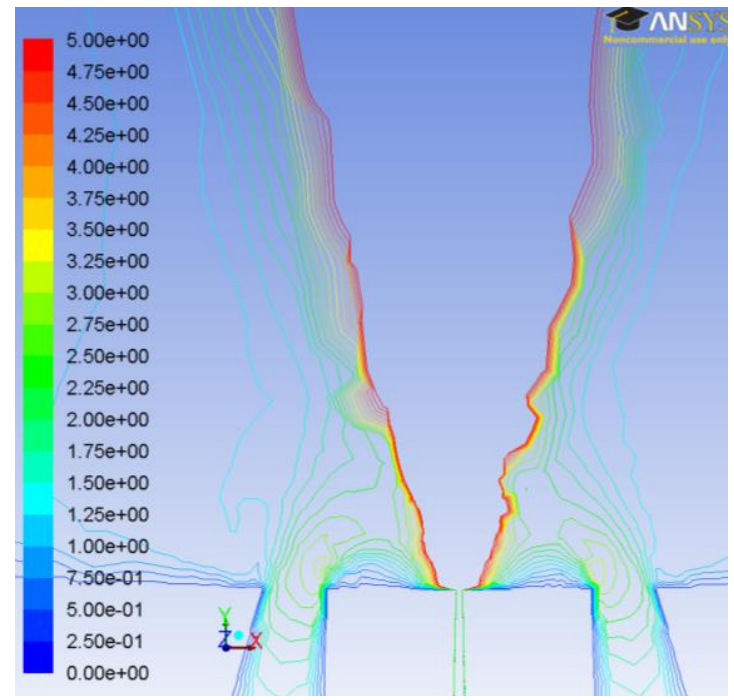

Figure 3. Contour of total velocity magnitude (0 to $5.0 \mathrm{~m} / \mathrm{s})$

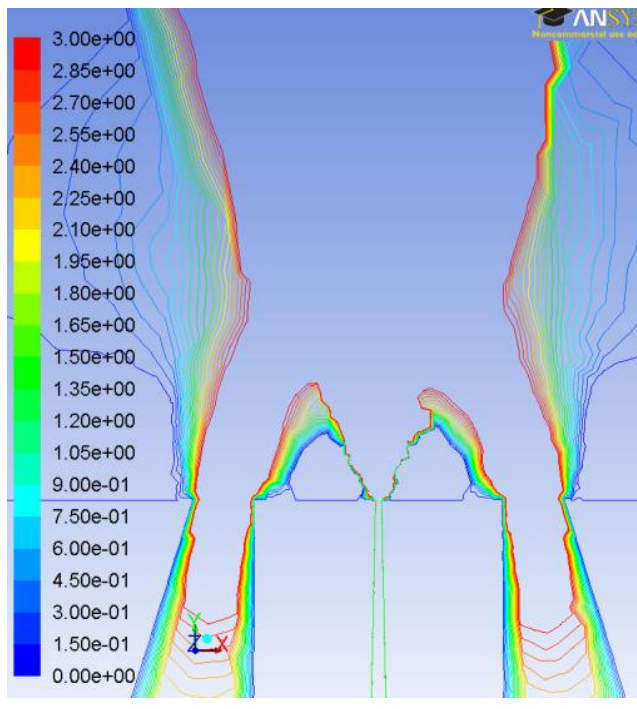

(a)

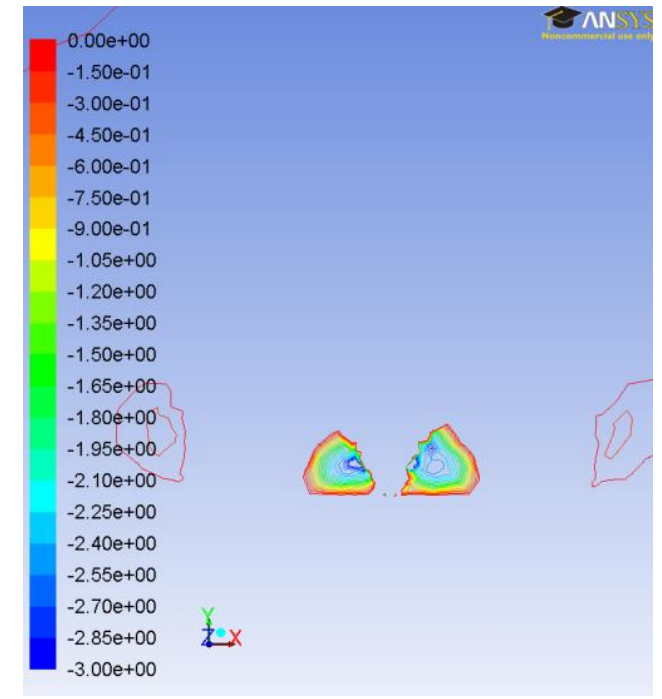

(b)

Figure 4. Contour of Y velocity, (a) 0 to $3.0 \mathrm{~m} / \mathrm{s}$, (b) -3.0 to $0 \mathrm{~m} / \mathrm{s}$.

The inner recirculation zone was formed as two circles, a big and small circle of the recirculation zone. Analysis of Figures 3, 4(a) and 4(b) shows that the recirculation zone can be divided into an inner and outer recirculation zone, as shown in Figure 5(b). Figure 5 shows that two types of recirculation zone are visualized in the swirl flow: the inner recirculation zone (IRZ) formed in between the air and fuel jet flow of the bluffbody, and the outer recirculation zone (ORZ) formed outside the annulus air flow. The recirculation zones were formed due to the bluff-body of the burner creating a swirl flow around the air and fuel nozzle. The air velocity flow is $5 \mathrm{~m} / \mathrm{s}$ and fuel is $70 \mathrm{~m} / \mathrm{s}$, while the width and the height of the recirculation zone were about 1 and 1.5 bluff-body diameters respectively. The recirculation of the mixture of fuel and air was important because that process will create the turbulent flow of the mixture which will enhance the mixing process. The intensity of the IRZ is higher than the ORZ because the IRZ is the 
recirculation formed in between the fuel and air jet flow. One cause of the higher intensity is the fuel jet velocity being much higher than the air jet velocity (Figure 3 ). In addition, the IRZ is contained in a small volume within the air jet and has two vortices due to jets on both sides (Figure 5(b)), while the ORZ occupies a bigger volume with a single vortex due to only one side being a jet.

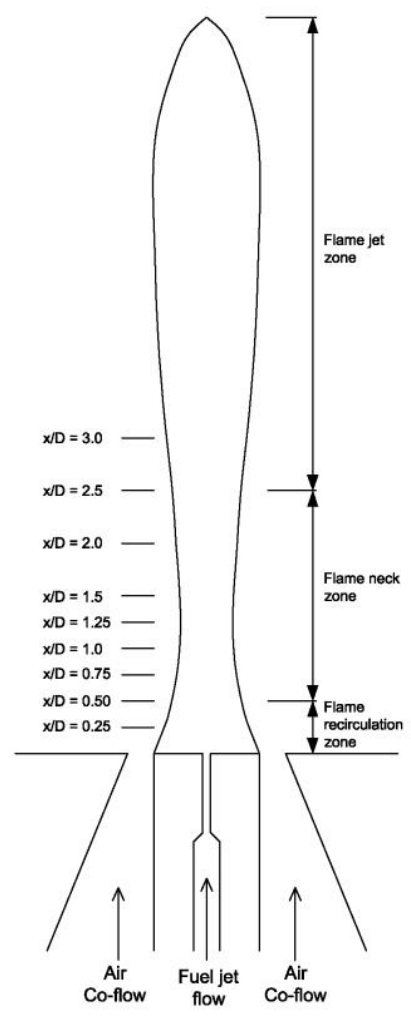

(a)

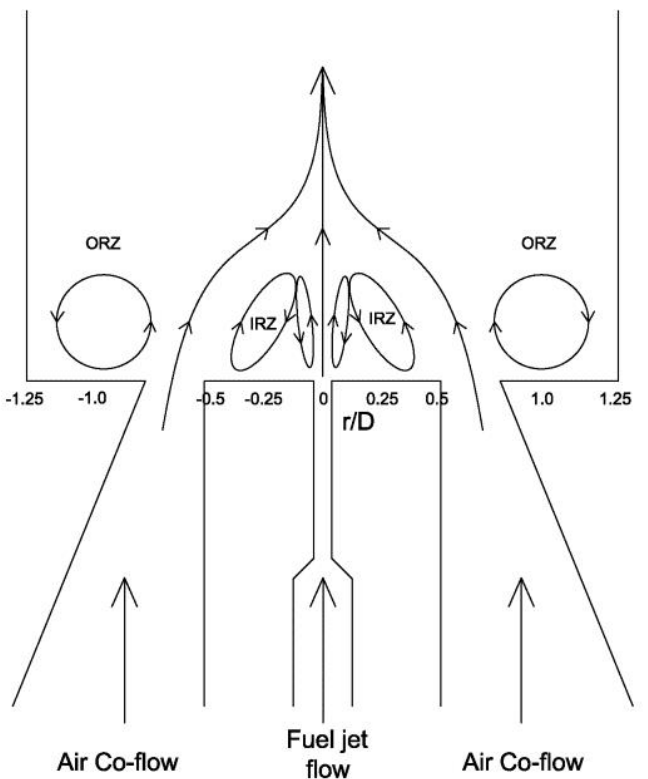

(b)

Figure 5. Schematic diagrams for bluff-body burner: (a) flame flow field with central fuel jet and annulus air co-flow; (b) flame re-circulation zone.

\section{SPARK IGNITION LOCATION}

Triantafyllidis, Mastorakos, and Eggels (2009) and Neophytou, Richardson, and Mastorakos (2012) concluded that the best location for ignition was in the center of the inner recirculation zone where the recirculation velocity is almost zero. This is important to ensure that the spark energy supplied by the tungsten rod was not flushed away, thereby giving sufficient time for the spark energy to ignite the mixture of fuel and oxidant. Figure 6 shows the design of the ignition rod installation, using the values from the CFD study: $\mathrm{x} / \mathrm{D}=0.25$ and $\mathrm{r} / \mathrm{D}=0.25$ (vertically $10 \mathrm{~mm}$ from the nozzle base and horizontally $10 \mathrm{~mm}$ from center of the nozzle). 


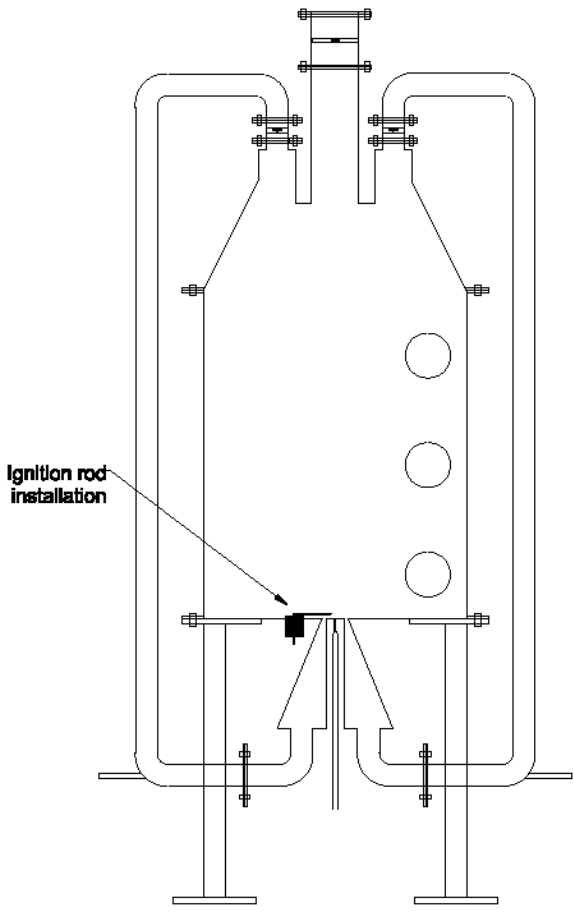

(a)

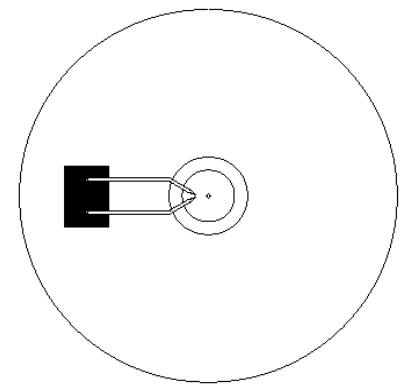

(b)

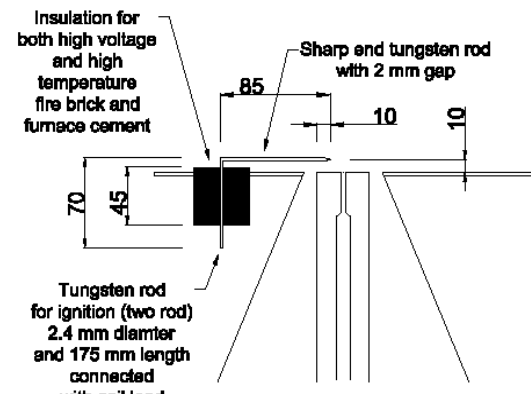

(c)

Figure 6. Schematic diagrams of combustion chamber: (a) ignition rod location; (b) location plan view; and (c) location side view of ignition location and installation.

\section{CONCLUSION}

A study on the recirculation zone and the ignition location for the non-premixed MILD combustion bluff-body burner was done using CFD. The recirculation zone was formed due to the bluff-body, increasing the turbulence of the flow of the fuel and air to make the mixture more homogeneous and mix better than the flow without turbulent flow. The center of the recirculation zone was the best location to install the spark ignition rod. From the analysis, the most suitable location with the highest possibility of ignition is the center of the recirculation zone. The center of the inner recirculation zone for the current design is $\mathrm{x} / \mathrm{D}=0.25$ and $\mathrm{r} / \mathrm{D}=0.25$.

\section{ACKNOWLEDGMENTS}

The authors would like to thank the University of Southern Queensland (USQ), Ministry of Higher Education, Malaysia (MOHE) and Universiti Malaysia Pahang (UMP) for providing financial support and laboratory facilities. The first author also thanks Associate Professor R. Mamat (UMP) and Abdul Aziz Hairuddin (UPM) for comments and discussions.

\section{REFERENCES}

Abtahizadeh, E., Oijen, J. V., \& Goey, P. D. (2012). Numerical study of mild combustion with entrainment of burned gas into oxidizer and/or fuel streams. Combustion \& Flame, 1596, 2155-2165. 
Ahmed, S. F., Balachandran, R., Marchione, T., \& Mastorakos, E. (2007). Spark ignition of turbulent non-premixed bluff-body flames. Combustion \& Flame, 151, 366-385.

Ahmed, S. F. (2006). Spark ignition of turbulent non-premixed flames (PhD thesis). Fitzwilliam College, University of Cambridge, UK.

Arghode, V. K. \& Gupta, A. K. (2010). Effect of flow field for colorless distributed combustion (CDC) for gas turbine combustion. Applied Energy, 87(5), 16311640 .

Arghode, V. K. \& Gupta, A. K. (2011). Development of high intensity CDC combustor for gas turbine engine. Applied Energy, 88, 963-973.

Aziz, A. R. A., Firmansyah, \& Shahzad, R. (2010). Combustion analysis of a CNG direct injection spark ignition engine. International Journal of Automotive and Mechanical Engineering, 2, 157-170.

Birch, A. D., Brown, D. R., \& Dodson, M. G. (1981). Ignition probabilities in turbulent mixing flows. Proceedings of Combustion Institute, 18, 1775-1780.

Cavaliere, A. \& de Joannon, M. (2004). MILD combustion. Progress in Energy and Combustion Science, 30, 329-366.

Cavaliere, A., de Joannon, M., \& Ragucci, R. (2008). Highly preheated lean combustion. In Lean combustion: technology and control (pp. 55-94). Oxford, UK: Elsevier.

Chandrasekharan, S., Nersessian, J. N., \& Subramanian, V. (2013). Computational modelling: is this the end of thought experiments in science? In Thought experiments in philosophy, science and the arts (pp. 240-260). London: Routledge.

Choi, G. M. \& Katsuki, M. (2002). Chemical kinetic study on the reduction of nitric oxide in highly preheated air combustion. Proceedings of the Combustion Institute, 29, 1165-1171.

Choi, G. M. \& Katsuki, M. (2001). Advanced low NOx combustion using highly preheated air. Energy Conversion and Management, 425, 639-652.

Chui, E. H. \& Raithby, G. D. (1993). Computation of radiant heat transfer on a nonorthogonal mesh using the finite-volume method. Numerical Heat Transfer B, 23(3), 269-288.

Colorado, A. F., Herrera, B. A., \& Amell, A. A. (2010). Performance of a flameless combustion furnace using biogas and natural gas. Bioresource Technology, 101(7), 2443-2449.

Dally, B. B., Karpetis, A. N., \& Barlow, R. S. (2002). Structure of turbulent nonpremixed jet flames in a diluted hot coflow. Proceedings of the Combustion Institute, 29(1), 1147-1154.

Dally, B. B., Riesmeier, E., \& Peters, N. (2004). Effect of fuel mixture on moderate and intense low oxygen dilution combustion. Combustion \& Flame, 137(4), 418-431.

Fluent Inc. (2011). Fluent 14.0 User's Guide

Ghobadian, B., Najafi, G., \& Nayebi, M. (2013). A semi-empirical model to predict diesel engine combustion parameters. Journal of Mechanical Engineering and Sciences, 4, 373-382.Hino, Y., Zhang, C., \& Ishii, T. (1998). Comparison of measurements and predictions of flame structure and NOx emissions in a gasfired furnace. AIAA/ASME Joint Thermophysics and Heat Transfer Conference, Albuquerque, New Mexico, USA.

IEA (2009). World Energy Outlook. Paris: International Energy Agency 
Ishii, T., Zhang, C., \& Sugiyama, S.,(1997). Numerical analysis of NOx formation rate in a regenerative furnace. Joint Power Generation Conference, Colorado, USA.

Katsuki, M. \& Hasegawa, T. (1998). The science and technology of combustion in highly preheated air. Proceedings of the Combustion Institute, 27(2), 3135-3146.

Keramiotis, C. \& Founti, M. A. (2013). An experimental investigation of stability and operation of a biogas fueled porous burner. Fuel, 103, 278-284.

Launder, B. E. \& Spalding, D. B. (1974). The numerical computation of turbulent flows. Computer Methods in Applied Mechanics and Engineering, 3(2), 269-289.

Lloyd, S. A. \& Weinberg, F. J. (1974). A burner for mixtures of very low heat content. Nature, 251, 47-49.

Maczulak, A. (2010). Renewable energy, sources and methods. New York, USA: Facts on File.

Marchione, T., Ahmed, S. F., \& Mastorakos, E. (2009). Ignition of turbulent swirling nheptane spray flames using single and multiple sparks. Combustion \& Flame, 156, 166- 180.

Mastorakos, E. (2009). Ignition of turbulent non-premixed flames. Progress in Energy and Combustion Science, 35, 57-97.

Mohanamurugan, S., \& Sendilvelan, S. (2011). Emission and combustion characteristics of different fuel in a HCCI engine. International Journal of Automotive and Mechanical Engineering, 3, 279-292.

Neophytou, A., Richardson, E. S., \& Mastorakos, E. (2012). Spark ignition of turbulent recirculating non-premixed gas and spray flames: a model for predicting ignition probability. Combustion \& Flame, 159, 1503-1522.

Noor, M. M., Wandel, A. P., \& Yusaf, T. (2012a). The modelling of the effect of air fuel ratio on unburned hydrocarbons for MILD combustion. $2^{\text {nd }}$ Malaysian Postgraduate Conference, 7-9 Jul., Bond University, Gold Coast, Australia, Paper No. MPC2012-27: 159-163.

Noor, M. M., Wandel, A. P., \& Yusaf, T. (2012b). Numerical investigation of influence of air and fuel dilution for open furnace mild combustion burner. Southern Regional Engineering Conference, Engineers Australia, 1-2 Sept., USQ, Paper No. SREC2012-002.

Noor, M. M., Wandel, A. P., \& Yusaf, T. (2012c). A review of MILD combustion and open furnace design consideration. International Journal of Automotive and Mechanical Engineering, 6, 730-754.

Oldenhof, E., Tummers, M. J., \& van Veen, E. H. (2010). Ignition kernel formation and lift-off behaviour of jet-in-hot-co-flow flames. Combustion \& Flame, 157(6), 1167-1178.

Oldenhof, E., Tummers, M. J., van Veen, E. H., \& Roekaerts, D. J. E. M. (2011). Role of entrainment in the stabilisation of jet-in-hot-co-flow flames. Combustion \& Flame, 158, 1553-1563.

Pomeroy, C. A. (2008). Science watch-biogas breakthrough. The Japan Journal, Nov., $1-3$.

Raj, C. \& Sendilvelan, S. (2010). Effect of oxygenated hydrocarbon additives on exhaust emission of a diesel engine. International Journal of Automotive and Mechanical Engineering, 2, 144-156.

Salunkhe, D. B., Rai, R. K., \& Borkar, R. P. (2012). Biogas technology. International Journal of Engineering Science and Technology, 4(12), 4934-4940.

Scholz, V. \& Ellner, J. (2011). Use of biogas in fuel cells - current R\&D. Journal of Sustainable Energy \& Environment, Special Issue, 11-15. 
Shafiee, S. \& Topal, E. (2009). When will fossil fuel reserves be diminished. Energy Policy, 37(1), 181-189.

Shih, T. H., Liou, W. W., Shabbir, A., Yang, Z., \& Zhu, J. (1995). A new k-e eddyviscosity model for high Reynolds Number turbulent flows-model development and validation. Computers and Fluids, 24(3), 227-238.

Triantafyllidis, A., Mastorakos, E., \& Eggels, R. L. G. M. (2009). Large eddy simulations of forced ignition of a non-premixed bluff-body methane flame with conditional moment closure. Combustion \& Flame, 156, 2328-2345.

Tsuji, H., Gupta, A., Hasegawa, T., Katsuki, M., Kishimoto, K., \& Morita, M. (2003). High temperature air combustion, from energy conservation to pollution reduction. Boca Raton, Florida: CRC Press.

Wandel, A. P., Noor, M. M., \& Yusaf, T. F. (2012). MILD combustion: a technical review towards open furnace combustion. International Journal of Automotive and Mechanical Engineering, 6, 731-752.

Weinberg, F. J. (1996). Heat-recirculating burners: principles and some recent developments. Combustion Science and Technology, 121, 3-22.

Wünning, J. (1991). Flammenlose oxidation von Brennstoff mit hochvorgewärmter Luft. Chemie Ingenieur Technik, 63(12), 1243-1245.

Wünning, J. G. (1996). Flammlose oxidation von Brennstoff (PhD Thesis). University of Technology, Aachen.

Wünning, J. A. \& Wünning, J. G. (1997). Flameless oxidation to reduce thermal noformation. Progress in Energy and Combustion Science, 23 (1), 81-94.

Zhang, C., Ishii, T., \& Sugiyama, S. (1997). Numerical modelling of the thermal performance of regenerative slab reheating furnaces. Numerical Heat Transfer, $32,613-631$. 